\title{
Analysis of Accountability Influence on Local Government Performance - A Case Study in a Local Government
}

\author{
Riska Natalisma ${ }^{1}$, Fransiskus Randa2, Ferdinandus Sampe ${ }^{3}$ \\ Department of Magister Accounting, Atma jaya Makassar University 1,2,3 \\ \{tatoranda@gmail.com²
}

\begin{abstract}
The study aims at investigating public accountability influence on government performance. Public accountability in form of legal accountability, honesty, process, policy, result, program and financial accountability as well as local government perferomance were identified. Data were collected from Toraja Regency - Indonesia. Questionnaires were sent to local government officers, members of local parliament, as well as public figures in Toraja Regency were interviewed. Seven hypotheses were tested. The results reveal that legal, honesty, process, policy, result, program and financial accountability have positive significant influence on local government performance. It is sugested that local parliamentary members and local pulic figures create a system in order to keep accountability of governmental activities.
\end{abstract}

Keywords: Public Accountability; Government; Performance; Indonesia

\section{Introduction}

Indonesia is still struggling hard to develop in various fields such as the economy, social and politics (Adrianto, 2007; Jamaluddin, 2017). The Republic of Indonesia is currently on period of recovery due to economic crisis (Nyman, Nilson \& Rapp, 2005). In such situation, the people's trust in the government is very important (Sudjiarto; 2000; Rasul, 2003). Trust in the government can be created if there is an accountability in public service (Lowman, 2017). So public accountability is one crucial requirement for Indonesia to catch up with other developed countries.

All parties including the government try to enhance the recovery period by carrying out reforms in all aspects to stimulate growth (Sudjiarto, 2000; Mardiasmo, 2002; Santoso \& Pambelium, 2008; Wijaya \& Akbar, 2013). Both central government and local governments promote good governance and public accountability to provide better public service performance (Wijaya, 2019). This actually emerged as a result of the development of the democratization process in various fields and the advancement of professionalism (Brown \& Moore, 2001; Schilleman \& Busuoic, 2014). Thus the government as the main actor of the implementation of good governance is demanded to provide more transparent and more accurate accountability (Chowdhury \& Panday, 2018). This is increasingly important to do in 
this era of reformation through empowering the role of control institutions as a counterweight to government power.

Public accountability has been the main concern in order to develop good governance (Nyman, Nilsson and Rapp, 2005; Rubin, 2013). This effort is also supported by many parties, both the government itself as an executive, the People Representative as a legislative institution, the press and also by non-governmental organizations (Monfoardini, 2010; Folwer $\&$ Cordery, 2015). The main elements of the effort to realize good governance are transparency, fairness, responsibility and accountability (Dumont, 2013). Whereas Hadori Yunus (2013) argues for increased efficiency in all fields (efficiency), clearer responsibilities (responsibility) and fairness (Fairness). During the era of reform, people in most parts of Indonesia, both in provinces, cities and districts began to be more aware on government performance (Santoso and Pembelum, 2008; Wijaya and Akbar, 2013). Managing public espenditure already become main concern of the people (Akbar, Robyn \& Ryan, 2012; Sarafina and Saifi, 2017).

The public wants to know further whether the government they have chosen has been operating economically, efficiently and effectively (Sinclair, 1995; Carr \& Ralph \& Brower, 2000; Ebrahim, 2003; Howlett \& Walker, 2012; Kaipers et al., 2014). In addition, it is one of the countries in the world that is struggling and longing for the creation of good governance (Ray, 2012; Lowman, 2017). To achieve good governance in governance in Indonesia, there are three pillars of good governance principles, namely the government, corporations, and civil society should mutually support and actively participate in the administration of governance that is being carried out.

Accountability as one of the important pillars / principles in good governance also has several principles that must be considered in order to effectively apply the concept of accountability (Salomonsen \& Knudsen, 2011; Aminuzzaman \& Khair, 2017; Peters, 2015, 2018). According to LAN \& BPKP (2000), in the implementation of environmental accountability of government agencies, accountability principles can be considered as follows: there must be commitment from the leadership and all agency staff to carry out the implementation of the mission to be accountable; must be able to show the level of achievement of the goals and objectives set; must be oriented towards achieving the vision and mission as well as the results and benefits obtained; must be honest, objective, transparent and innovative as a catalyst for change in management of government agencies in the form of updating performance measurement methods and techniques and preparing accountability reports.

Accountability that is understood by the government as an agent is 1) dominant accountability is measured from the managerial aspect of the output in the form of a government accountability report and 2) MUSREMBANG media as a communication channel has not run according to the mandate of the law. Thus the accountability is built more on the political economy aspects of the government as an agent (Political economic accountability).

The accountability that the DPRD understands as the principal's representative shows that 1) political accountability is more dominant and the tendency of the members of the council to side with the government and 2) the existing accountability communication media such as MUSREMBANG, the process and the gathering of people's aspirations have not been used maximally and tend to be ceremonial media in the interest the politics of the Members of the Council. When the results of understanding public accountability mentioned above become the basis in designing models and indicators of public accountability in this study.

The results of the identification are then processed in the form of the results of the public accountability model (Randa and Pasoloran, 2015) which identify 7 factors that can influence 
public accountability (Randa \& Pasoloran, 2018). The model is described as follows. The study was to investigate the influence of accountability on local government performance.

\section{Literature Review}

\subsection{Conceptual Definition}

Accountability is defined as the relationship between the party who holds the control and regulates the entity and the party who has formal power over the controlling party (Monfadini, 2010; Vasely, 2013; Igboyi et al, 2016). In this case accountable third parties are also needed to provide explanations or reasonable reasons for all activities carried out and the results of operations obtained in connection with carrying out a task and achieving a particular goal.

According to Dummont (2013) public accountability has traditionally been understood as a tool used to oversee and direct administrative behavior by giving obligations to be able to provide answers (answerability) to a number of external authorities. According to Parkhurst (2017) public accountability in the most fundamental sense refers to the ability to answer to someone related to expected performance. Someone given this answer must be someone who has the legitimacy to conduct oversight and expect Government performance

Government financial reports must provide information that can be used by users of financial statements to assess government accountability in making economic, social and political decisions (Mauro, 1998; Brown-Safii, 2013; Holmberg and Rothstein, 2012). In the context of the administration of government, government accountability cannot be known without the government informing the people about information relating to community resources and sources of funds and their use (Halachmi and Greilling, 2013).

\subsection{Perspective of Accountability}

Accountability can be viewed from accounting, functional, and accountability system perspectives (Jackson \& Palemer, 1992; Harman, 1994; Hicklin \& Godwin, 2009; Joss, 2010; Grimmelikhuijsen et al., 2013; Parkhurst, 2017; Hartley and Zang, 2018). The perspectives provide different understanding of accountability.

Accounting perspective views accountability of a government as an entity. Accountability can be divided into four groups (Kluvers \& Tippett, 2011), namely accountability for financial resources, compliance with legal rules and administrative policies, the efficiency and economy of an activity, the results of government programs and activities that are reflected in the achievement of objectives, benefits and effectiveness.

Functional perspective views accountability as a level with five different levelss that begin from a stage that requires more subjective measures (Kaihatu, 2012). These levels are probilty and legality accountability - concerns accountability in the use of funds in accordance with the approved budget and in accordance with applicable laws and regulations (compliance); process accountability - relates the processes, procedures, or measures used in carrying out the specified activities (planning, allocating and managing), performance accountability - whether the activities carried out are efficient and efficient, program accountability - relates to determination and achievement of the goals set (outcomes and effectiveness), and policy accountability - selection of various policies will be applied or not (value).

Accountability system perspective concerns focus on results (outcomes), use several indicators that have been selected to measure performance, produce information that is useful 
for decision making on a program or policy, produce data consistently from time to time and report the results (outcomes) and publish regularly.

\subsection{Accountability Dimension}

Researchers provide analytical tools to assess accountability dimension. Halim (2007) divide accountability dimension as legal accountability and honesty, process accountability, program accountability and policy accountability.

a. Legal Accountability and Honesty - the accountability of public institutions to behave honestly in their work and to obey the applicable legal provisions. The use of public funds must be done properly and have obtained authority (Gregory \& Lonti, 2008). Legal accountability is related to compliance with other laws and regulations that are required in running an organization, while honesty accountability is related to the avoidance of abuse of power, corruption and collusion. Legal accountability requires law enforcement, while honesty accountability requires healthy organizational practices without malpractice and maladministration.

b. Process Accountability - accountability processes related to procedures used in carrying out tasks are good enough in terms of the adequacy of accounting information systems, management information systems, and administrative procedures. Process accountability is manifested through the provision of public services that are fast responsive, and inexpensive.

c. Program Accountability-is concerned with considering whether the objectives set can be achieved or not, and whether the organization has considered alternative programs that provide optimal results with minimal costs. Public institutions must take responsibility for the programs that have been made up to the implementation of the program means that organizational programs should be quality programs that support the strategy and achievement of the organization's mission, vision, and goals.

d. Accountability Policy. Policy accountability is related to the accountability of public institutions for policies taken. Public institutions should be able to account for policies that have been determined by considering the impact in the future. In making policies must consider what the objectives of the policy are, why the policy was taken, who is the target, which stakeholders (stakeholders) will be affected and obtain benefits and (negative) impacts on the policy.

\subsection{Previous Research Review}

Some results of accountability research in public sector organizations show the importance of accountability as a factor needed by each organization (Clarkson, 2010; Sankin \& Schneider, 2010; Kluvers and Tippett, 2011; Wafa, 2016). Randa (2015) shows that the dominant understanding of public accountability is measured from the managerial aspect of identifying the understanding of public accountability by the community, local government and board members as stakeholders. Accountability understood by the community is 1) the availability of infrastructure that supports community activities, 2) The use of the Development Planning Conference (MUSREMBANG) as an effective communication channel in accommodating the interests of the community, and 3) managerial accountability is poorly understood and not an indicator of the success of the local government.

Riantiarno and Azlina(2010) had researched public accountability in Rokan Hulu Regency and find out that legal accountability had significant influence on local government 
performance while financial acountability had positive but not significant influence on local government perfrormance.

Nyman, Nilsson and Rapp (2005) have studied accountability in Swedish local gaovernment and find that clarity is the main problem in governmental accountability. Mzenzi and Gaspar (2015) have studied the influence of external auditing on governmental accountability and found that external auditing marginally influence the enhancement of Tanzanian Local Governments authorities.

\subsection{Hypothesis Development}

\section{a) Processes Accountability Influence Government Performance}

Halimdan Abdullah (2006) states that agency arises in a budget preparation process that is seen from the perspective of the relationship between the people and the legislative and legislative branches with the executive having the relationship between the executive being the agent and the legislature being the principal while the legitimacy is the leadership of the government that occupies positions and power, theoretical research results which are grouped based on process accountability according to Hopwood \& Tomkis (1984), (Randa \& Pasoloran, 2018) state that related to the procedures used in carrying out tasks are good enough in terms of the adequacy of accounting information systems, management information systems, and administrative procedures. Process accountability is manifested through the provision of public services that are fast responsive, and inexpensive.

Based on this theory and the results of this study, it can be hypothesized that : H1: Process accountability influences government performance.

\section{b) Legal Accountability Influences Government Performance}

Based on the theory of legitimacy is an act of applicable law or existing regulations, both formal legal regulations, customs, and public law that has long been legally created. Syahrudin Rasul, 2002 states that legal accountability is related to compliance with law and other compliance required in the organization. Legal accountability guarantees the upholding of the rule of law, Randa \& Pasoloran, 2018 states the implementation of laws or law enforcement and follow-up of potential legal violations, while accountability is honest about governance practices and conspiracies in setting and implementing budgets. So based on this theory and the results of this study it can be hypothesized that:

H2: Legal accountability influences government performance

\section{c) Accountability Honesty Affects Government Performance}

Honesty accountability is related to avoidance of misuse, corruption and collusion, honesty accountability about governance practices and conspiracy in the determination and implementation of budgets (Sihaloko, 2013; Alom, 2018). So based on this theory and the results of this study it can be hypothesized that:

H3: Accountability Honesty affects government performance 


\section{d) Accountability Policies Affect the Performance of Government}

Syahrudin Rasul, 2002 said that policy accountability is related to the accountability of public institutions for the policies taken. Public institutions should be able to account for policies that have been determined by considering policies that have been determined by considering the impact in the future. Whereas in the theory of legitimacy in the broadest sense is community support for the political system. in addition, in making policies must consider the objectives of the policy, why the policy was taken, who is the target, which stakeholders (stakeholders) will be affected and benefit and impact (negative) on the policy. Based on this theory and the results of this study, it can be hypothesized that:

H4: Accountability Policies affect government performance

\section{e) Accountability Results Affect the Performance of Government}

Agency theory assumes that only interested in increased financial results or investments then the agency makes mechanisms that will be used as mechanisms of legitimate interests. Randa \& Pasoloran (2018) state that the accountability of results is in line with the expectations and needs of the community and the quality of building facilities and infrastructure. Based on this theory and the results of this study, it can be hypothesized that: H5: Accountability results affect government performance.

\section{f) Accountability Programs Affect Government Performance}

Program accountability is concerned with considering whether the objectives set can be achieved or not, and whether the organization has considered alternative programs that provide optimal results with minimal costs. Public institutions must take responsibility for the programs that have been made up to the implementation of the program means that organizational programs should be quality programs that support the strategy and achievement of the organization's mission, vision, and goals (Samkin and Schneider, 2010; Bovens et al, 2014). And based on the theory of legitimacy is community support for the government authorities. In addition, in this dimension stakeholders or parties who make and carry out policies are required to achieve the vision and mission of the organizational goals. Based on these theories and the results of this study, it was hypothesized that:

H6: Program accountability influences government performance

\section{g) Financial Accountability Influences Government Performance}

Randa and Pasoloran, 2018 stated that their main focus was on accurate and timely reporting on the use of public funds, which is usually done through professionally audited reports. The main objective is to ensure that public funds have been used for the purposes set out efficiently and effectively. The main problem is the timeliness in preparing reports, audit processes, and audit quality. Special attention is paid to performance and value for money and enforcement of sanctions to anticipate and overcome abuse, for example management or corruption. Based on this theory and the results of this study, it was hypothesized that:

H7: Financial accountability influences government performance. 


\section{Research Method}

\subsection{Research Design}

The design of this study uses explanatory research (explanatory research), which is research that aims to test a theory or hypothesis in order to strengthen or even reject a theory or hypothesis that has already existed. This study explains the relationship between two or more symptoms or variables, and uses 8 variables, namely:

a. Dependent Variable is a variable that is observed and measured by researchers in a study, to determine whether there is an influence of an independent variable, which in this study is the performance of government.

b. Independent variables are variables that influence or cause changes, which in this study are legal accountability, honesty accountability, process accountability, policy accountability, results accountability, program accountability, financial accountability.

\subsection{Population and Research Samples}

The population in this study is the House of Representatives (DPRD) and the office of the Human Resources Development and Human Resources Agency (BKPSDMD) Tana Toraja. The sample is representative of the population whose results represent the overall symptoms observed. The samples in this study are the executives and legislators and the Board Members in Tana Toraja who are the representations of the stakeholders based on the purposive sampling method.

\subsection{Types and Data Sources}

The questionnaire distributed by researchers consisted of 5 Legal Accountability Items, 4 honesty accountability items, 4 process accountability items, 5 policy accountability items, 5 outcome accountability items, 7 program accountability items, 5 Financial accountability items, and 8 government performance items.

\subsection{Data Collection Methods}

The data in this study were obtained using a survey method that is data obtained using a questionnaire that was distributed directly (Tana Toraja) to the executives and legislators in the Office of the House of Representatives (DPRD Tana Toraja) and the BKPSDDM office of Tana Toraja the questionnaire was returned and sent by respondents directly directly to researchers to ensure confidentiality. The questions presented in the questionnaire are closed questions using a 5 point Likert scale with $1=$ strongly disagree, $2=$ disagree, $3=$ neutral, $4=$ agree, and $5=$ strongly agree.

\subsection{Operational Definition and Variable Measurement}

\section{a) Legal Accountability}

Legal accountability related to compliance with laws and other regulations required in the organization, and legal accountability guarantees the rule of law upheld. The indicators used in this study are the Larkin indicators and then formulate them into 5 questions with a Likert 
scale of 1 to 5 that are favorable (positive statements that correspond to the dimensions of the measured variable). This indicator is also used by Imani (2014) and Arianti (2015).

\section{b) Honesty Accountability}

Accountability Honesty is related to avoidance of misuse of office, and honesty accountability guarantees healthy organizational practices. This variable is measured using 4 question items with the four questions being favorable questions consisting of 5 Likert scale points. This indicator has been used by Mardisar and Sari (2007), Icuk and Elisha (2010), Harjanto (2014), Ariviana (2015).

\section{c) Process Accountability}

Accountability processes related to procedures used in carrying out tasks are good enough in terms of the adequacy of accounting information systems, management information systems, and administrative procedures. Process accountability is manifested through the provision of public services that are fast responsive, and inexpensive. There are 4 question items used by researchers, which are favorable consisting of 5-point Likert scale.

\section{d) Policy Accountability}

Public institutions should be able to account for policies that have been determined by considering the impact in the future. In making a policy, consideration must be given to the objectives of the policy, why the policy was carried out, into 5 items that are favorable questions on a Likert scale of 1 to 5 .

\section{e) Results Accountability}

Theory of the assumption is assumed that only interested in increased financial results or investments then the agency makes mechanisms that will be used as mechanisms of legitimate interests. Randa \& Pasoloran (2018) state that the accountability of results is in line with the expectations and needs of the community and the quality of infrastructure and facilities development. Researchers used 5 favorable question items consisting of a Likert scale of 1 to 5.

\section{f) Program Accountability}

Program accountability also means that organizational programs should be quality programs and support strategies in achieving the organization's vision, mission and goals, public institutions must be held accountable for programs that have been made up to program implementation. And on this dimension the stakeholders or parties who make and carry out the policy are required to achieve the vision and mission of the goals of the organization. Researchers use 7 items of favorable nature consisting of a Likert scale of 1 to 5 . 


\section{g) Financial Accountability}

This accountability is the responsibility of public institutions to use public funds (Public money) economically, efficiently and effectively, there is no waste and leakage of funds, and corruption. Financial accountability is very important because it is the main focus of the community. This accountability requires public institutions to make financial reports to illustrate the financial performance of the organization to outsiders. Researchers use 5 question items that are favorable consisting of a Likert scale of 1 to 5.

\section{h) Government Performance}

Government performance is defined as the result of government activities and programs that are to be or have been achieved in relation to the use of the budget with measurable quality (PP number 8 of 2006). According to Nordiawan (2010) government performance cannot be seen only in terms of inputs and outputs but also in terms of outcomes, benefits and impacts on community welfare. Researchers use 8 question items that are favorable consisting of a Likert scale of 1 to 5

\subsection{Test Validity}

Validity test is used to test whether the instrument is in accordance with what you want measured in a study. This test is used to measure the validity of a questionnaire, and whether the dimensions measured can really be the items in the measurement. The approach used is concept validity (construct validity) by correlating the score of each item with the total score. The correlation technique used is Pearson's Correlation Product Moment. If the Pearson Correlation value is positive and has a significance level $\leq 0.05$ and below 0.05 , then the question is valid in measuring the concept (Ghozali, 2011).

The whole variables have Pearson Correlation between between $0.392-0,648$, or a significance level of 0,000-0.001 which means that each item of questions is able to measure legal accountability (valid).

\subsection{Reliability Test}

The reliability test aims to measure whether the measuring instrument used produces consistent answers over time. The reliability measurement in this study uses the Cronbach Alpha statistical test. An instrument is said to be reliable or consistent if it has a Cronbach Alpha value of ,0.60. The higher the Cronbach Alpha value, the more consistent a variable is (Ghozali, 2011).

\subsection{Normality Test}

The normality test is one of the assumption tests that needs to be met in order to carry out parametric tests. This test can see whether the regression model, the dependent variable and the independent variable have a normal distribution. A good regression model is normally distributed or near normal data. Tests on the normality of the data used Smirnov colmograph testing criteria using probability $(\rho)$ obtained with a significant level $(\alpha) 0.05$. If the value of $\rho>\alpha$, then the data is normally distributed (Ghozali, 2011). Based on the results of the 
normality test presented in Table 3.4, the equation used in this study has a sig value. 0.402 ( $>$ 0.05 ), thus indicating that the data used in this study are normally distributed.

\subsection{Multicollinearity Test}

Multicollinearity test aims to test the possibility of finding correlations between independent variables in the regression model. In a good regression model, there should be no correlation between the independent variables. If the independent variables are correlated with each other, then this variable is not orthogonal, which means that the variable correlation value between fellow variables is equal to zero. To detect the presence or absence of multicollinearity in the regression model, a test is used to look at the tolerance value and its opponent, the inflation factor value.

Multicollinearity test is done by looking at the value of VIF (Variance Inflation Factor) in the path analysis model. In general, if VIF $>10$, then the variable has multicollinearity problems with other independent variables. If VIF $<10$ then there are no symptoms of multicollinearity (Ghozali, 2011). Based on the multicollinearity test results, all research variables have tolerance values above 0.100 and VIF values below 10.00, which means no multicollinearity occurs.

\subsection{Heteroscedasticity Test}

The heteroscedasticity test aims to test whether in the regression model there is an unequal variance from the residuals of one observation to another. If the variance from one observation residual to another observation is fixed, then it is called homoscedasticity and if different is called heteroscedasticity. A good regression model is homoscedasticity or heteroscedasticity does not occur.

To detect heteroscedasticity using the Glesjer method, namely by regressing the absolute value of residuals. If the test results obtained a probability value ( $P$ value $)>0.05$, it can be said there are no symptoms of heteroscedasticity. Conversely, if the test results obtained a probability value $(\mathrm{P}$ value $)<0.05$, it can be said that there are symptoms of heteroscedastasis (Ghozali, 2011).

\section{Results and Discussion}

\subsection{Profile of Respondents}

This research was conducted by distributing questions to Board Members and BKPPD offices using a questionnaire. Data collection procedures in this study were carried out by distributing questionnaires directly to correspondents who were in the Toraja Regency who were the object of research. The number of questionnaires sent in this study were 65,0 were not responded to and the rest were 65. Descriptive respondents were used to find out the percentage of respondents' demographic characteristics. Respondents in this study were board members and community shops. Descriptive respondents in this study were in the form of gender, DPRD members and BKPPD offices. The majority of respondents came from men, namely $42(64.6 \%)$ people, then women as many as 23 people $(35.4 \%) .1 \%)$, and 37 BKPPD offices $(37.9 \%)$. 


\subsection{Descriptive Statistics Results}

Seven independent variables for accountability and one dependent variable for government performance were assessed. The result is presented on table 1 .

Table 1. Descriptive Findings

\begin{tabular}{lcccc}
\hline \multicolumn{1}{c}{ Variable } & Theoretical Range & Actual Range & Mean & Std. Dev. \\
\hline Legal Accountability & $5-25$ & $18-25$ & 23,26 & 1,81 \\
Honesty Accountability & $4-20$ & $13-20$ & 17,53 & 1,67 \\
Process Accountability & $4-20$ & $8-19$ & 16,03 & 1,88 \\
Policy Accountability & $5-25$ & $13-23$ & 20,09 & 1,71 \\
Results Accountability & $5-25$ & $12-25$ & 15,18 & 2,34 \\
Program Accountability & $7-35$ & $19-31$ & 27,00 & 1,97 \\
Financial Accountability & $5-25$ & $13-22$ & 19,76 & 1,56 \\
Government Performance & $8-40$ & $25-38$ & 30,00 & 2,24 \\
\hline
\end{tabular}

Source: Analysis Data Collected For The Study

Based on table1, it can be seen that the range of theoretical values of the legal accountability variable is set at $5-25$, and the value of the answers given by respondents ranges from 16-24, with a mean value of 19.72, and a standard deviation of 2.103 . This illustrates that respondents tend to give answers strongly agree (answer score 5) and some give answers agree (answer score 4) of questionnaire questions, which means that most stakeholders carry out their duties in accordance with established criteria and pay more attention to regulations applicable law.

The theoretical range value of the honesty accountability variable is set at $4-20$, and the value of the answers given by respondents is between, 14 - 20 with a mean value of 17.60; and a standard deviation of 2.052. This illustrates that respondents tend to give answers strongly agree (answer score 5) and partly give neutral answers (answer score 3) to the questionnaire questions items given, which means that most stakeholders assume that they are not in compliance with the rules and avoid any action which can make people doubt the accountability of honesty.

The range of theoretical values for the process accountability variable is set at $4-20$, and the value of the answers given by respondents ranges from 13-20, with a mean value of 16.32; and standard deviation of 2,237. This illustrates that respondents tend to give answers agree (answer score 4) and some give neutral answers (answer score 3) to the questionnaire questions items given, which means some stakeholders are responsible for their work.

The range of theoretical values for policy accountability variables is set at 5-25, and the value of the answers given by respondents ranges from 16-25, with a mean value of 20.55; and standard deviation of 1,912. This illustrates that respondents tend to agree (answer score 4 ) to the questionnaire questions items given, which means that most stakeholders are responsible in government policy.

The range of theoretical values of the outcome accountability variable is set at $5-25$, and the value of the answers given by respondents ranges from $12-25$, with a mean value of 17.31 ; and a standard deviation of 3.082. This illustrates that respondents tend to answer neutral (answer score 4) to the questions given questionnaire questions, which means that most stakeholders are responsible for their work.

The range of theoretical values for the program accountability variable is set at 7-35, and the value of the answers given by respondents ranges from 19-32, with a mean value of 26.97 ; and a standard deviation of 2.084. This illustrates that respondents tend to answer agree 
(answer score 4) and neutral (answer score 3) to the questionnaire questions items that are given, which means that most government planning stakeholders produce government programs.

The range of theoretical values of financial accountability variables is set at 5-25, and the value of the answers given by respondents ranges from 13-25, with a mean value of 18.95; and the standard deviation of 2.478. This illustrates that respondents tend to answer agree (answer score 4) to the questionnaire questions items that are given, which means most stakeholders pay more attention to financial accountability.

The range of theoretical values of government performance variables is set at 8-40, and the value of the answers given by respondents ranges from 26-38, with a mean value of 30.95; and standard deviation of 2,678. This illustrates that respondents tend to answer neutral (answer score 3 ) and agree (answer score 4) to the questionnaire questions items that are given, which means that most stakeholders in order to produce the right opinion.

Table 2. Results of Multiple Linear Regression Analysis

\begin{tabular}{llccc}
\hline \multicolumn{1}{c}{ Exogenous Var. } & Endogenous Var. & $\begin{array}{c}\text { Unstandardized } \\
\text { Beta Coef. }\end{array}$ & Sig & Influence \\
\hline Legal Accountability & Govern-ment & 0,482 & 0,035 & Sig. \\
Honesty Accountability & perform-ance (Y) & $-0,735$ & 0,007 & Sig. \\
Proccess Accountability & & $-0,818$ & 0,028 & Sig. \\
Policy Accountability & 1,045 & 0,011 & Sig. \\
Result Accountability & & 0,272 & 0,033 & Sig. \\
Program Accountability & & 1,271 & 0,000 & Sig. \\
Financial Accountability & Source: Data Analysis & & Sig. \\
\hline
\end{tabular}

Based on table 2, the multiple linear regression equation is obtained as follows: $\mathrm{Y}=0,482 \mathrm{X} 1-0,735 \mathrm{X} 2-0,818 \mathrm{X} 3+1,045 \mathrm{X} 4+0,272 \mathrm{X} 5+1,271 \mathrm{X} 6-0,450 \mathrm{X} 7$

The results of the regression equation above explain that:

a. Effect of legal accountability on government performance. The accountability variable has an unstandardized beta coefficient value of legal accountability of 0.231 with sig. 0.007 , which means that accountability has a positive influence on government performance or with increasing stakeholder accountability, statistically will improve government performance. And statistically this effect is good with the magnitude of the effect of the variable legal accountability (on government performance $(Y)$ of $(0.231 \times 100 \%)=23,1 \%$.

b. The Effect of Honesty Accountability on Government Performance.The honesty accountability variable has an unstandardized beta coefficient on government performance of 0.191 with a value of sig.0.35, which means that honesty accountability has a positive effect, meaning that the more the accountability of honesty the better the performance of the government. And statistically this effect is good with the magnitude of the effect of the honesty Accountability variable (on government performance $(\mathrm{Y})$ of $(0.191 \times 100 \%)=$ 19,1\%.

c. Effect of Process Accountability on Government Performance. Process Accountability Variable has an unstandardized beta coefficient on government performance of 0.270 with sig. 0.001 which means that if the influence is positive, it means that the accountability of the process increases, the better the performance of the government. And statistically the effect is good with the magnitude of the effect of the process accountability variable (on government performance $(\mathrm{Y})$ of $(0.270 \times 100 \%)=27 \%$ 
d. Effect of Policy Accountability on Government Performance. Policy Accountability Variable has an unstandardized beta coefficient value of government performance of 0.355 with a value of sig. 0,001 which means that policy accountability has a positive influence on government performance or with increasing accountability of policies owned by stakeholders, then statistically will increase government performance by $(0.355 \times 100 \%)$ $=35.5 \%$

e. Effect of Results Accountability on Government Performance. The Accountability Variable Result has an unstandardized beta coefficient value of government performance of 0.125 with a value of sig. 0,000 which means that Accountability results have a positive influence on government performance or by increasing accountability of results owned by stakeholders, then statistically will improve performance good government. Variability Accountability results (on government performance $(\mathrm{Y})$ of $(0.125 \times 100 \%)=12.5 \%$.

f. The Effect of Program Accountability on Government Performance. Program Accountability Variable has an unstandardized beta coefficient value of government performance of 0.166 with a value of sig. 0,133 which means that program accountability has a positive influence on government performance or with increasing accountability of programs owned by stakeholders, statistically will increase government performance and statistically the effect good, with the magnitude of the effect of program accountability variables (on government performance $(\mathrm{Y})$ of $(0.166 \times 100 \%)=16.6 \%$.

g. Effect of Financial Accountability on Government Performance. Financial Accountability Variable has an unstandardized beta coefficient on government performance of 0.134 with a value of sig. 0.005 which means that financial accountability has a positive influence on government performance or with increasing financial accountability owned by stakeholders, then statistically will increase government performance by $(0.134 \times 100 \%)$ $=13.4 \%$.

\subsection{Testing Hypotheses}

a. Relationship between legal accountability and government performance Hypothesis 1 states that legal accountability has a significant effect on government performance. Based on the results of statistical testing t, legal accountability has an influence of 0.231 and a probability of significance of 0.007 , smaller than 0.05 . It can be concluded that legal accountability has a positive and significant influence on government performance. Thus, X1 which states that legal accountability has a significant effect on government performance, is accepted.

b. Relationship of honesty accountability with government performance Hypothesis 2 states that honesty accountability affects government performance Based on the results of statistical testing $t$ Honesty accountability has an effect of 0.191 and a significance probability of 0.035 , smaller than 0.05 . It can be concluded that honesty accountability has a positive and significant effect on government performance. Thus, X2 which states that honesty accountability has a significant effect on government performance, is accepted.

c. Relationship between process accountability and government performance Hypothesis 3 states that process accountability influences government performance Based on the results of statistical testing t Process accountability has an influence of 0.270 and a significance probability of 0.001 , smaller than 0.05 . It can be concluded that process accountability has a positive and significant influence on government performance. Thus, 
X3 which states that process accountability has a significant effect on government performance, is accepted.

d. Relationship between policy accountability and government performance Hypothesis 4 states that policy accountability has a significant effect on government performance. Based on the results of statistical testing t, policy accountability has an effect of 0.355 and a probability of significance of 0,000 is smaller than 0.05 . It can be concluded that policy accountability has a positive and significant influence on government performance. Thus, X4 which states that policy accountability has a significant effect on government performance, is accepted.

e. Relationship between outcome accountability and government performance Hypothesis 5 states that the accountability of results has a significant effect on government performance. It can be concluded that the accountability of results has a positive and significant effect on government performance. Thus, X5 which states that the accountability of results has a significant effect on government performance, is accepted.

f. Relationship between program accountability and government performance Hypothesis 6 states that program accountability has a significant effect on government performance. Based on the results of statistical testing t, program accountability has an effect of 0.166 and a probability of significance of 0.013 , smaller than 0.05 . It can be concluded that program accountability has a positive and significant effect on government performance. Thus, X6 which states that program accountability has a significant effect on government performance, is accepted.

g. The relationship between financial accountability and government performance Hypothesis 7 states that financial accountability influences government performance. Based on the results of statistical testing t, Financial accountability has an effect of 0.134 and a probability of significance of 0.005 , smaller than 0.05 . It can be concluded that financial accountability has a positive and significant influence on government performance. Thus, $\mathrm{H} 7$ which states that financial accountability has a significant effect on government performance, is accepted.

\subsection{Discussion}

Related to avoiding misuse of office, bureaucrats compliance with law and guarantees of law enforcement, as well as other regulations that are required in the use of public resources measured in applicable regulations and encouraging employees in local governments to obey the law. This study found that legal accountability has a positive effect and significant to government performance $(\mathrm{Y})$, which means that the higher the accountability of a stakeholder, the higher the performance of local government will be public institutions to behave honestly in work and obey the applicable legal provisions. The use of public funds must be done properly and have obtained authority. Legal accountability is related to compliance with other laws and regulations that are required in running the organization Syahrudin Rasul, 2002 states that legal accountability is related to compliance with laws and other compliance required in the organization.

Accountability honesty is an awareness of the behavior or actions that encourage a person to be able to bear all the consequences of his actions that will affect himself or others. An honest person is an individual who carries out his work thoroughly with good results because it is influenced by the feeling that his work is an obligation that must be carried out in accordance with existing regulations, so that the results given are in accordance with the standards imposed on him. To produce opinions that are in accordance with existing standards, 
a person must be able to be honest in his work and actions. Not only limited to adhering to existing standards or regulations, a person needs to understand honesty in order to make objective decisions, and communicate his decisions or opinions with coworkers or teammates to create a cooperative work environment. This study found that accountability in honesty had a partial impact on government performance because the respondents concerned in this case the stakeholders assumed that the government was still not honest. Accountability honesty is a process and not one that is taken for granted. Being accountable must be manifested in real activities, not just sitting down and expressing criticism. "Being accountable means working with the community and other stakeholders to improve the honesty and performance of the government (public bureaucrats), and not avoid criticism. Proactive behavior demanded by accountability can be understood as a proactive process through which government officials (public officials) inform their action plans, their behavior, and results, and be sanctioned when committing deviations (Ackerman, 2005). An assessment or sanction is an important part of accountability. The assessment shows whether the government has worked in accordance with public preferences (Boven, 2006) related to avoidance of misuse, corruption and collusion, honesty accountability about governance practices and conspiracy in the determination and implementation of the budget. This study found that legal accountability (X2) has a positive effect on government performance (Y), which means that the higher the accountability of honesty possessed by a stakeholder, the better the government performance produced will be.

Hopwood \& Tomkis (1984), states that related to the procedures used in carrying out the task is good enough in terms of the adequacy of accounting information systems, management information systems, and administrative procedures. Jay M. Sharitz \& E. W Russel (2007) Decision making has met the applicable ethical standards and values which means that it is in accordance with the principles of correct administration with clarity of policy objectives taken and in accordance with the organization's vision and mission and applicable standards. There is a mechanism to ensure that the standard has been met with the consequences of the accountability mechanism if the standard is not met, as well as the consistency and feasibility of the established operational targets and priorities in achieving these targets. Process accountability is manifested through the provision of public services that are fast responsive, and inexpensive. This research found that process accountability has a positive influence on government performance $(\mathrm{Y})$, which means that the better the accountability of honesty possessed by a stakeholder, the better government performance will result. Accountability process is a budgeting process that only disturbs the performance of the government, having a sense of responsibility will tend to do everything possible to carry out the task, both in designing audit procedures to the decision making stage with a commitment that the audit process must be completed properly and on time in order to provide quality opinions. In addition, they are also influenced by the idea that the preparation of working papers that include budget planning.

Effect of Policy accountability on Government Performance - Syahrudin Rasul, 2002 claimed that policy accountability is related to the accountability of public institutions for the policies taken. The policy socialization stage is by disseminating information about a decision, through mass media, personal communication media. Completeness of information relating to ways to achieve the objectives of a program, as well as, public access to information on decisions made and community complaints mechanisms. Public institutions should be able to account for policies that have been determined by considering policies that have been determined by considering the impact in the future. This research found that policy accountability) has a positive and significant influence on government performance (Y), which means that the higher the accountability of policies owned by a stakeholder, the higher 
government performance will result. related to the responsibility of both central and regional government for policies taken by the government towards the legislature and the wider community.

Accountability of results according to the expectations and needs of the community and the quality of development of facilities and infrastructure. This study found that the accountability of results (X5) has a positive and significant effect on government performance $(\mathrm{Y})$, which means that the higher the accountability of the results owned by a stakeholder, the higher government performance produced will be.

Program accountability is concerned with considering whether the objectives set can be achieved or not, and whether the organization has considered alternative programs that provide optimal results with minimal costs. Public institutions must take responsibility for the programs that have been made up to the implementation of the program means that organizational programs should be quality programs that support the strategy and achievement of the organization's mission, vision, and goals (Samkin and Schneider, 2010; Bovens et al, 2014). And based on the theory of legitimacy is community support for the government authorities. in addition, on this dimension stakeholders or parties who make and implement policies are required to achieve the vision and mission of the organization's goals. This research found that program accountability (X6) has a positive and significant effect on government performance $(\mathrm{Y})$, which means that the higher the accountability of a program owned by a stakeholder, the better the government performance produced.

This has a program accountability which tends to be good in carrying out its duties because it is able to understand the existing situation and think about what it has to do in completing budget programs. to be able to convince the government in accordance with the standards or expectations imposed on it.

To create quality financial reports, there is a need for accountability for the preparation of financial reports in the central and regional governments, including financial integrity, disclosure, and observance of legislation. area. The main instruments of regional financial management accountability are local government budgets, periodically published data, annual reports and investigation results and other general reports prepared by agents. This study found that financial accountability (X7) has a positive influence on government performance (Y), which means that the better financial accountability a stakeholder has, the better government performance will result. This shows that a person is responsible for financial integrity, disclosure and compliance with laws and regulations, his main focus is financial reporting that is accurate and timely about the use of public funds that include receipts, storage and expenditure. which means that in the preparation of finances is still low and actually interfere with government performance.

\section{Conclusion}

This research was conducted to examine the effect of legal accountability, honesty accountability, process accountability, policy accountability, outcome accountability, program accountability, and financial accountability on government performance with respondents consisting of community leaders and board members in the Tana Toraja district. The conclusions of this study are as follows legal accountability, policy accountability, results accountability and program accountability have a positive influence on government performance. Then the better the honesty accountability, policy accountability, results accountability and program accountability, the better the government performance. While 
honesty accountability, process accountability and financial accountability have a negative influence on government performance.

\section{Research Implications}

a. Theoretical Implications - this research can provide theoretical implications for the development of science, especially for the development of attribution theory so that the results of this study can be used as academic learning materials that there are several factors that affect government performance such as legal accountability, honesty accountability, process accountability, accountability, policies, accountability for results, accountability for programs, and financial accountability. Attribution theory can use the finding of the effect of legal accountability, honesty accountability, process accountability, policy accountability, outcome accountability, program accountability, and financial accountability on government performance in this study as materials to develop an understanding of the influence of external and internal factors on individual performance, in which External and internal factors have a big and strong influence on the quality level of the individual's performance.

b. Practical Implications, this research can provide practical implications as learning for stakeholders to increase and maintain their commitment and efforts in carrying out the accountability process, continue to hone their education and experience which is useful in determining and designing procedures so that they can detect errors or mistakes, both intentional and unintentional; uphold and obey all the regulations that bind it so that public views and trust in government performance are good.

\section{Limitations}

During the course of this research, the researcher has limitations that have an impact on the research results, such as:

a. Researchers used a survey method through distributing questionnaires without interviews or oral communication. So that researchers cannot obtain more in-depth and real information, apart from the questions in the questionnaire, which may be too narrow or cannot describe the real situation to confirm the existing research results.

b. The only variables used are legal accountability, honesty accountability, process accountability, policy accountability, results accountability, program accountability, and financial accountability that can affect government performance.

\section{Avenue for Future}

Based on the research results that have been concluded, there are several suggestions that can be taken into consideration by future researchers in order to obtain additional perspectives:

a. Preferably, in further research, include a direct interview process as a means of confirming research data so that the information obtained becomes more precise.

b. Further research can be carried out to add variables that may influence the government.

\section{References}

[1] Adrianto,Nice.2007. Good Government : Transparansi dan Akuntabilitas Publik melalui e-Government. Palangkaraya: Bayu Media . 
[2] Auditya (2013). Analisis Pengaruh Akuntabilitas dan Transparansi Pengelolaan Keuangan Daerah Terhadap Kinerja Pemerintah Daerah. Jurnal Fainess Volume 3, Nomor 1: 21-42 (ISSN 2303-0348).

[3] Akbar, R. P. Robyn, and P. Brian. 2012. Performance Measurement in Indonesia: The Case of Local Government. Pacific Accounting Review, 24 (3), 262-291.

[4] Alom, M.M. (2018) "Proactive transparency and outward accountability of frontline public bureaucracies: An integrated model", International Journal of Productivity and Performance Management, Vol. 67 Issue: 4, pp.611-628,

[5] Aminuzzaman, S.M dan Khair, S. (2017), Strengthening anti-corruptin agencies in Asia Pacific, Bangladesh: Transparency International.

[6] Baswir, Revrisond,2000,Akuntansi Pemerintahan Indonesia,BPFE, Yogyakarta.

[7] Brown, L.,\& M. H.Moore.(2001). Accountabilty ,a Strategyon International Non Goverment. England: Harvard University

[8] Budimanta dkk(2008)\&Rizki,(2010) Theory Stakeholder

[9] Carr, Jared B \& Ralph S. Brower,2000, Principal opportunism : Evidence from the organizational middle ,'Public Administration Quarterly (Spring ): 109-138

[10] Chowdhury, S. dan Panday, P.K. (2018). Public Administration, Governance and Globalization, Switzerland: Springer International Publishing

[11] Clarkson ,B. E. M 2010 . A stakeholder Framework for analysing and evaluating corporate social performance. Academy of Management Review,92-117.

[12] Craft, J., \& Howlett, M. (2012). Policy formulation, governance shifts and policy influence: Location and content in policy advisory systems. Journal ofPublic Policy,32(2), 79-98

[13] Dumont, G.E. (2013), "Transparency or accountability? The purpose of online technologies for nonprofits", International Review of Public Administration, Vol. 18 No. 3, pp. 7-29.

[14] Ebrahim,A.(2003).Accountability in Practice: Mechanism for NGOs. World Development, 13Ramlan Surbakti, Memahami Ilmu Politik,(PT. Gramedia, Jakarta, 1992).

[15] Eisenhardt .K.M., (2008) Agency Theory : An Assessment and Review."Academy of management Review, Vol,14 (1).Pp 57-74

[16] Fowler, C.J. Cordery, C.J. (2015) "From community to public ownership: a tale of changing accountabilities", Accounting, Auditing \& Accountability Journal, Vol. 28 Issue: 1, pp.128-153

[17] Freeman, R.E (1984) Strategic Mangement:A Stakeholder Approach .Boston,MA Pitman.

[18] Fukuyama, F. (2013). What is governance? Governance, 26(3), 347-368.

[19] Gray, kouhy\&adams (1994) \&Ghozali,Imam dan AnisChariri 2007.Teori Akuntansi.Semarang: Badan Penerbit Universitas Diponegoro

[20] Gregory, R., \& Lonti, Z. (2008). Chasing shadows? Performance measurement of policy advice in New Zealand government departments. PublicAdministration, 86(3), 837-856.

[21] Grimmelikhuijsen, S., Porumbescu, G., Hong, B. and Im, T. (2013), "The effect of transparency on trust in government: a cross-national comparative experiment", Public Administration Review, Vol. 73 No. 4, hal. 575-586

[22] Hadori Yunus (2013). Akuntansi Keuangan Lanjutan Edisi Pertama.Yogyakarta: BPFE. 
[23] Halachmi, A. and Greiling, D. (2013), "Transparency, e-government, and accountability”, Public Performance \& Management Review, Vol. 36 No. 4, pp. 562584.

[24] Halim,Abdul.2007.”Akuntansi Sektor Publik: Akuntansi Keuangan Daerah". Jakarta: Salemba

[25] Hapwood dan Tomkinks juga Elwood (2005:10 yang diterjemakan oleh Mahmudi bahwa "Dimensi akuntabilitas yang harus dipenuhi oleh lembaga-lembaga publik. Jurnal Akuntansi.

[26] Harman,E (1994):"Accounting and Challenges for Australian Government's Austaralia Journal of Political Science Empat

[27] Hartley, K. dan Zhang, J. (2018). Measuring Policy Capacity Through Governance Indices, In Xun Wu, Michael Howlett, M. Ramesh (Eds) : Policy Capacity and Governance. Cham, Switzerland : Palgrave Macmillan, hal.67 - 97

[28] Hicklin, A., \& Godwin, E. (2009). Agents of change: The role of policy managers in public policy. Policy Studies Journal, 37(1), 13-20.

[29] Holmberg, S., \& Rothstein, B. (2012). Good government: The relevance of political science. Cheltenham: Edward Elgar.

[30] Howlett, M., \& Walker, R. M. (2012). Public managers in the policy process: More evidence on the missing variable? Policy Studies Journal 40(2), hal. 211-233.

[31] Igboyi, L.S., Nweze, A.U., Enekwe, C.I., Nze, D. (2016). "Effect of Probity and Accountability on the Development in Nigeria", Research Journal of Finance and Accounting, Vol.7, No.18, hal 1-13.

[32] Jamaluddin, Y. 2017.Analisis terhadap indikator pengukuran akuntabilitas kinerja Kementrian Badan Usaha Milik Negara - 2015. Jurnal TAPIs Vol.14 No. 01 Januari Juni 2017

[33] Jensen,M.C and Meckling,W.H. 1976“Theory of Firm Management Behaviour Agency Cost \& Ownership Structure”. Journal of Financial Economics. Vol.3 P $\rho .305-360$

[34] Joss, S. (2010), "Accountable Governance, Accountable Sustainability? A Case Study of Accountability in the Governance for Sustainability", Environmental Policy and Governance No. 20, hal. 408-421.

[35] Kaihatu, Thomas, 2012. Good Corporate Governance dan penerapannya di Indonesia. Jurnal Manajemen dan Kewirausahaan, vol. 8 no. 1, hal. Pp. $14-22$

[36] Kluvers, R dan Tippett, J. (2011), "The Views of Councillors and Managers on Accountability in Local Government: An Empirical Study in Australia” International Journal of Management Vol. 28 No. 2 hal. 519 - 527

[37] Kuipers, B. S., Higgs, M., Kickert, W., Tummers, L. G., Grandia, J., \& Van der Voet, J. (2014). The management of change in public organisations: A literature review. Public Administration, 92(1), 1-20.

[38] Lembaga Administrasi Negara dan Badan pengawasan keuangan dan pengembangan RI (2000). Akuntabilitas dan good governance, modul 1-5, modul sosiaslisasi sistem Akuntabilitas Kinerja Instansi Pemerintah (AKIP). Jakarta : LAN BPKP RI.

[39] Lowman, M. (2017). A Practical Guide to Analytics for Governments - Using Big Data for Good, New Jersey : Willey \& Sons.

[40] Mardiasmo 2002, Otonomi \& Manajemen Keuangan Daerah, Yoyakarta: Penerbit Andi

[41] Martini, M. dan Murphy, M. 2018. G20 Leaders or Lagg ards? Reviewing G20 promises on ending anonymous companies, Transparency International.

[42] Mauro,P 1998. Corruption and the composition of government expenditure. Journal of Publik Economics 69: 263-279. 
[43] Moeheriono, 2012, Indikator Kinerja Utama (IKU) Bisnis dan Publik, Jakarta : Raja Grafindo Persada.

[44] Monfardini, P. (2010) "Accountability in the new public sector: a comparative case study", International Journal of Public Sector Management, Vol. 23 Issue: 7, hal. 632646

[45] Nyman, C., Nilsson, F. dan Rapp, B. (2005) "Accountability in local government: a principal agent perspective", Journal of Human Resource Costing \& Accounting, Vol. 9 Issue: 2, pp.123-137

[46] Parkhurst, J. (2017) The Politics of Evidence - From evidence-based policy to thegood governance of evidence. London : Routledge

[47] Permana,Bayu Aji , 2012 Jurnal Akuntansi Universitas Negeri Surabaya.

[48] Peters, B. G. (2015). Pursuing horizontal management: The politics of public sectorcoordination. Lawrence: University Press of Kansas.

[49] Peters, B. G. (2018). Policy Capacity in Public Administration, In Xun Wu, Michael Howlett, M. Ramesh (Eds) : Policy Capacity and Governance. Cham, Switzerland : Palgrave Macmillan, hal. 29 - 47

[50] Randa,F.\&Pasoloran (2018). Pengujian Model Akuntabilitas Publik Pada Organisasi, Seminar Nasional UKIP

[51] Randa,F (2015) Devoloping Accountability Modal of local Government Organization: From Managerial Accountability to Publik Accountbility (Naturalistic Study on Local Government Tana Toraja) Procedia -Social and Behavioral Sciences. 665-672

[52] Rasul,Syahrudin,2003. Pengintegrasian Sistem Akuntabilitas Kinerja dan Anggaran dalam Perspektif UU NO.17/2003 Tentang Keuangan Negara Jakarta : PNRI.

[53] Ray, S. (2012) "Reinforcing accountability in public services: an ICT enabled framework", Transforming Government: People, Process and Policy, Vol. 6 Issue: 2, pp. $135-148$

[54] Rubin, I. (2013). The politics of public budgeting: Getting and spending, borrowingand balancing. Washington, DC: CQ Press

[55] Rusli, B. (2014), Isu-Isu Krusial Administrasi Publik Kontemporer, Bandung ; LEPSINDO.

[56] Sadjiarto, A. (2000). “Akuntabilitas dan pengukuran kinerja pemerintahan”,Jurnal Akuntansi \& Keuangan, Vol. 2, No. 2, hal. $138-150$

[57] Salim,P.1991.Kamus Bahasa Kontemporer. Jakarta :Modern English Fresh.

[58] Salomonsen, H. H., \& Knudsen, T. (2011). Changes in public service bargains: Ministers and civil servants in Denmark. Public Administration, 89(3), 1015 - 1035.

[59] Samkin, G. dan Schneider, A. (2010) "Accountability, narrative reporting and legitimation: The case of a New Zealand public benefit entity", Accounting, Auditing \& Accountability Journal, Vol. 23 Issue: 2, hal.256-289.

[60] Santoso, U. Dan Pambelum, Y. J. (2008) Pengaruh Penerapan Akuntansi Sektor Publik Terhadap Akuntabilitas KinerjaInstansi Pemerintah Dalam Mencegah Fraud Jurnal Administrasi Bisnis (2008), Vol.4, No.1: hal. 14-33,

[61] Sarafina, S. dan Saifi, M. (2017) "Pengaruh Good Corporate Governance terhadap kinerja keuangan dan nilai perusahaan (Studi pada Badan Usaha Milik Negara (BUMN) yang Terdaftar di Bursa Efek Indonesia Periode 2012-2015)",Jurnal Administrasi Bisnis (JAB)|Vol. 50 No. 3 hal. $108-117$

[62] Schillemans, T. and Busuioc, M. (2014), "Predicting public sector accountability: from agency drift to forum drift", Journal of Public Administration Research and Theory, Vol. 25 No. 1, pp. 191-215. 
[63] Sinclair, A (1995). "The Chameleon of Accountability: Forms and Discourses".Accounting, Organizations and Society. 20 (2/3):219-237.

[64] Sihaloho, Johannes.2013. Pengaruh Tekanan Eksternal, Ketidakpastian Lingkungan dan Komitmen Manajemen terhadap penerapan Tranparansi Pelaporan Keuangan (Studi Pada Satuan Kerja Perangkat Daerah Pemerintah Kabupaten Rokan Hilir, Fakultas EkonomiAkuntansi: Universitas Riau.

[65] Siregar, V.S., \& Utama, S. 2010. Type of Earnigs Management and the Effect of Ownership Structure, Firm Size and Corporate Governance Practice.

[66] Soelendro,Arie.2000.Paradigma Baru Aparat Pengawasan Intern Pemerintah Makalah.Kongres Akuntan Indonesia IV. Jakarta.

[67] Sofyani,H. Dan Akbar, R. (2013). Hubungan faktor internal institusi dan implementasi sistem akuntabilitas kinerja instansi pemerintah (SAKIP) di pemerintah daerah, Jurnal Akuntansi dan Keuangan Indonesia, Desember 2013, Vol. 10, No. 2, hal $184-205$.

[68] Suherman. 2007. Penelitian Masalah tentang Penerapan Good Coorporate Governance pada Dunia Usaha. Badan Pembina Hukum Nasional Depertemen Hukum dan Hak Asasi Manusia.

[69] Supriatna,Tjahya.2013,Manajemen Pemerintahan Daerah, Bandung: IPDN

[70] Turner Mark and Hulme, David,1997.Governance, Administrasi, and Development: Making The State Work. London: Mac Millan Press Ltd

[71] Vesely, A. (2013). Externalization of policy advice: Theory, methodology and evidence. Policy and Society, 32, 199-209.

[72] Wafa, D.M. (2016) "Proxies of public interest: deficits of social accountability mechanisms in the Arab region", International Journal of Public Leadership, Vol. 12 Issue: 4, pp.301-316

[73] Wijaya, A. H. C. and R. Akbar. 2013. The Influence of Information, Organizational Objective and Targets, and External Pressure toward The Adoption of Performance Measurement System in Public Sector. Journal of Indonesian Economy and Business, $28,62-83$.

[74] Wiranto, Tatag : Akuntabilitas dan Transparansi dalam Pelayanan Publik. 